organic mass spectrometry. This small book (five chapters) is a useful addition to the somewhat neglected area of physical mass spectrometry. Although based on an undergraduate, or first year postgraduate, course, it should prove of value beyond this limited sphere, in particular to the incrcasing number of organic mass spectroscopists scarching for a deeper insight into ion roaction mechanisms. The emphasis, as one might expect, is on a wide scops, stressing principles and conclusions, but involving minimal mathematical detail.

The logical layout commences with a study of ion molecule reactions emphasizing theoretical treatments of collision processes. Then follows a very good account of ionization mechanisms. particularly those which occur in mass spectromoter sources or have been studied by mass spectrometry. The instrumentation chapter is open to criticism in that less familiar instruments, for example the quadrupole, receive too brief a coverage. This is unfortunate because magnet instruments, which are covered in greater detail, are adequately covered in every other text. The application section avoids the pitfall of duplicating familiar organic examples and concentrates on quantitative measurements. These include mixture analysis, with several inorganic examples, and the evaluation of thermochemical data from measured ionization and appearance potentials. Armed with these experimental data, the final chapter, largely concerned with the "Quasi Equilibrium Theory", illustrates clearly both the success, and the limitations, of the theory to date.

Throughout the text diagrams are clearly drawn, and when coupled with the brief but pertinent bibliography they make this a most readable book.

\section{B. Blessington}

Vogt, remarked that the God of the Vestiges is a very British constitutional monarch, who first lays down laws and then pledges himself not to interfere with their operation. All changes in the uriverse were preordained by laws fixed at the moment of creation.

Chambers had a modest competence as a geologist, but in most topics his naive uncritical credulity stimulated pertinent and destructive criticism. The Cambridge professor of geology, Adam Sedgwick, thundered for nearly 90 pages in the July 1845 number of the Edinburgh Review, which Darwin read "with fear and trembling, but was well pleased to find that I had not overlooked any of the arguments". Sedgwick's review drew a response from Chambers in Explanations in which he reviews and defends his argument, showing great technical skill and grasp of his wide-ranging source material. It is a pity tho re-publication of Explanations has not been undertaken, because Chambers appears in it in a much more favourable light. Sedgwick's obsession with Vestiges led to his famous fifth edition of his Discourse on the Studies of the University of Cambridge, preceded by a preliminary dissertation of 342 pages and followed by an appendix of a further 227 pages. (The discourse itself occupies a mere 94 pages.) We know that Darwin read this extremely forceful criti. cism of the idea of transmutation by August 12, 1850. Ho annotated his copy very fully and returned in 1856 to make further annotations and extracts in preparing to write the Origin in its first lengthy version. There is no doubt that Darwin observed Sedgwick's shrewd hits and sought to armourplate his own arguments at the weak spots revealed in Chambers. In short, the Vestiges proved invaluable to Darwin when planning his strategy. This reprinting of the first edition of Vestiges is accordingly a most welcome event. May we now have its sequel, the Explanations?

SydNey SMITH.

\title{
ONE MAN'S VIEW
}

\section{Vestiges of the Natural History of Creation} By Robert Chambers, (The Victorian Library.) Pp. 390. (Leicester University Press: Leicester; Humanities Press: New York, May 1969. First published 1844.) $50 s$.

THIs reissue of tho first edition of Robert Chambers's Vestiges by the University of Leicester makes available to the student of Victorian times and of the history of the transmutation theory a document of paramount importance. For its handsome production and durable Cambridge blue plastic binding the price asked is most reasonable. The original printer, T. C. Savile, of 107 St Martin's Lane, is, however, not allowed credit for good typesetting and handsome margins. His name and address are absent from the last page of text. An introduction of 20 pages outlining the position and significance of the Vestiges for the general reader has been contributed by Sir Gavin de Beer, the Charles Darwin Scholar. This reprint, alas, is like tho first edition in having no index.

Professor Owen Chadwick in his recent history, The Victorian Church, remarks on the Vestiges of the Natural History of Creation: "Among books it was unique in bcing simultaneously discredited and powerful. Touch it with a little finger and it fell. And in falling it seemed the debris of a strange half-hidden magnetic synthesis of new knowledge." Published with carefully guarded anonymity in October 1844, its British sales in cloven editions were nearly 24,000. Darwin's Origin had sold 22,000 copies of the English edition by the time of his death in 1882 .

Chambers argued that all known species were derived by descent from lower forms to higher, the second highest giving birth to man. Creation was continuous. (xod having ordained the course of transmutation at the moment of creation had no further noed to interfere in His activity. A German critic and translator, Karl

\section{FISH PHYSIOLOGY}

\section{Olfaction in Fishes}

By Herman Klecrekoper. Pp. viii + 222. (Indiana University Press: Bloomington and London, June 1969.) $\$ 12.50$.

MR KLEEREKOPER reviews comprehensively the literature of significance produced during the past hundred years on olfaction in fishes. The significance of olfaction in the behaviour has, as the author states in the preface, been documented in scattered papers over many years. Many have been overlooked or forgotten; the author has now made them readily available. He also summarizes expertly recent electrophysiological and electron microscope work which has given a new insight into the understanding of the olfactory system.

Chapter one is an account of the morphology and function of tho olfactory organ in fishes. The outline of the development of the olfactory organs in different fishes reminds us that there is still speculation whether monorhiny was a primary or secondary development and that the single olfactory groove of cyclostomes is not homologous with Kollicker's groove in Branchiostoma and does not constitute a phylogenetic link to the olfactory organ of higher vertebrates. This chapter is equally stimulating in its troatment of the origin of the olfactory epithclium, and olfactory cells. Mention is made of acute sensitivity of olfaction in fishes, not only in the perception of very minute concentration of odours at molecular level, but also in the discrimination of odours in mixtures of smells. It is distressing to lcarn that the chemical make-up of biologically important smells is largely unknown. It is thus not possible to determine thresholds in the physiological sense because to do this we would need to know the molecular identity of the smell and its concentration in the mixture. The amount of work that needs to be done is enormous, but 